\title{
Chemical composition of volatile and extractive compounds of pine and spruce leaf litter in the initial stages of decomposition
}

\author{
V. A. Isidorov ${ }^{1}$, M. Smolewska ${ }^{1}$, A. Purzyńska-Pugacewicz ${ }^{1}$, and Z. Tyszkiewicz ${ }^{2}$ \\ ${ }^{1}$ Institute of Chemistry, Bialystok University, 15-399 Białystok, Poland \\ ${ }^{2}$ Department of Environmental Protection and Management, Bialystok University of Technology, 15-351 Białystok, Poland
}

Received: 31 January 2010 - Published in Biogeosciences Discuss.: 15 March 2010

Revised: 3 September 2010 - Accepted: 6 September 2010 - Published: 21 September 2010

\begin{abstract}
A litter bag experiment was conducted to analyze changes in chemical composition in Scots pine (Pinus sylvestris) and Norway spruce (Picea abies) needle litter in the first stages of decomposition in natural conditions. The emission rates of monoterpenes and concentration of extractive secondary metabolites were determined five times over a 16-month period. It has been shown that pine and spruce needle litter in the first stages of decomposition (up to 165 days) emits monoterpene hydrocarbons into the gas phase with the rates comparable to those in emissions from live needles of these trees. This suggests that leaf litter is an important source of atmospheric terpenes. It has also been proved that the litter contains considerable amounts of nonvolatile substances that can be precursors of oxidized volatile compounds formed as a result of enzymatic reactions. Nonvolatile but water soluble secondary metabolites of the leaf litter may be involved in nutrient cycling and have an influence on soil community.
\end{abstract}

\section{Introduction}

Biogenic reactive volatile organic compounds (VOCs) have been attracting attention of atmospheric chemists mainly in relation with the estimation of biogenic contributions to the atmospheric carbon budget, as well as with the problems of tropospheric ozone and aerosol particles production. Emissions of volatile VOCs from living vegetation are well documented, and have been quantified in a number of recent emission inventories (Guenther et al., 1995, 2000; Simpson et al., 1999; Isidorov et al., 1999; Lindfors and Laurila, 2000; Solmon et al., 2004; Smiatek and Steinbrecher, 2006; Steinbrecher et al., 2009). The upper limit of the evaluation

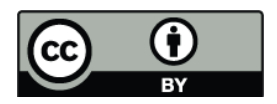

Correspondence to: V. A. Isidorov (isidorov@uwb.edu.pl) of global phytogenic VOCs emission is $1300-1500 \mathrm{Tg} \mathrm{yr}^{-1}$ (Isidorov, 1990; Guenther et al., 1995; Guenther, 2002). The production and emission pathways of phytogenic VOCs are described by Kesselmeier and Staudt (1999) and Guenther et al. (2000). Gas phase oxidation and conversion of biogenic volatile organic compounds into particles was also discussed thoroughly in literature (Hoffmann et al., 1997; Griffin et al., 1999; Atkinson, 2000; Seinfeld and Pankow, 2003; Kulmala et al., 2004).

The data collected in the cited publications, as well as in many other sources, have been used for the evaluation of the impact of phytogenic emissions on the chemical environment of the lower atmosphere. Above all, the emission data are used as a basis for the development and application of atmospheric models (Kang et al., 2003; Curci et al., 2009). However, currently drawn conclusions as to the impact of VOCs on the atmospheric chemistry seem to be rather vague and significantly connected with the uncertainties related to the scale and variation of VOCs fluxes (Curci et al., 2009). According to Guenther et al. (2000), model estimates of total VOCs emission can differ by a factor of 5-10 for some landscapes. A potential source of atmospheric VOCs that is often ignored is leaf litter, and dry deposition of VOCs to the earth surface is another process that is often underestimated. Both of these problems have been attracting some attention in the last decades, but neither has been sufficiently well studied. The present study addresses only one of these problems, i.e. leaf litter emission of VOCs. The potential importance of this source of emission results evidently from its large scale: for land ecosystems, the litter biomass is estimated to be $(5-80) \times 10^{15} \mathrm{~g}$ (Zavarzin, 1984). In the volatile emissions of litter of seven species of deciduous and coniferous trees 14 monoterpenes and more than 60 organic compounds of other classes were identified (Isidorov and Janova, 2002; Isidorov et al., 2003).

Zimmerman et al. (1978) were evidently the first to estimate the emission rate of VOCs emitted by leaf litter.

Published by Copernicus Publications on behalf of the European Geosciences Union. 
According to their data, it averages $162 \mu \mathrm{g} \mathrm{m}^{-2} \mathrm{~h}^{-1}$ at $30^{\circ} \mathrm{C}$. There are only few direct measurements of VOCs emission from leaf litter in natural environments, or even such laboratory experiments. Beside that, the results of field experiments and conclusions can be contradictory even within the same working group. For instance, Janson (1993) determined monoterpenes emission from pine forest floor on two plots in the 140-year-old stand of Scots pine in the southern Sweden. The emission rate in July normalized to $20^{\circ} \mathrm{C}$ was $21 \mu \mathrm{g} \mathrm{m}^{-2} \mathrm{~h}^{-1}$. The emission in October on these plots was much higher $\left(104\right.$ and $\left.580 \mu \mathrm{g} \mathrm{m}^{-2} \mathrm{~h}^{-1}\right)$ than the summer emission. According to the authors' estimation, the emission rate from the pine forest floor amounted to $30 \%$ of the crown emission. However, later measurements (Janson et al., 1999) in coniferous forest and wetland in southern Sweden in the summer and early autumn gave considerably lower flux (up to $50 \mu \mathrm{g} \mathrm{C} \mathrm{m}^{-2} \mathrm{~h}^{-1}$ ) of monoterpenes. Thus, in the latter series of experiment the BVOC flux from the forest floor made up only a few percent of the total forest flux.

Relatively slow summer (27-29 July 1999) emission rates from an undisturbed plot of forest floor in a Sitka spruce forest were also registered by Hayward et al. (2001). Total daily monoterpene emission rates, normalized to $30^{\circ} \mathrm{C}$, varied from 28.3 to $38.4 \mu \mathrm{g} \mathrm{m}^{-2} \mathrm{~h}^{-1}$ (average $33.6 \mu \mathrm{g} \mathrm{m}^{-2} \mathrm{~h}^{-1}$ ). According to the authors' estimation, the foliar emission rate was ca. 38 times greater than the calculated monoterpene emission rate from the undisturbed soil of this type of forest.

Stepanov (1999) conducted the measurements of monoterpenes with the static chamber technique in July-October 1998 in a Norway spruce (Picea abies) forest near St. Petersburg, Russia. Emission rates from forest floor with needle litter varied from 20.9 to $402.0 \mu \mathrm{g} \mathrm{m}^{-2} \mathrm{~h}^{-1}$ from the same plots. The highest terpene emissions were observed in the early autumn at the temperature $5-6^{\circ} \mathrm{C}$; as a rule, they were substantially higher than summer emissions at the temperature $20-25^{\circ} \mathrm{C}$. The existence of a surface terpene source was confirmed in the experimental determination of the diurnal vertical profiles of terpene in the same forest (Isidorov et al., 1999). In the conditions of a stable stratification of the atmosphere, maximum monoterpene concentrations were observed on a level with the centre of tree crowns (ca. $9 \mathrm{~m}$ above the ground), and in the near-ground air (below $0.8 \mathrm{~m}$ ). These observations correspond well with the vertical ambient air measurements of monoterpenes in a 138 year old forest of Scots pine in Sweden (Janson, 1992): the nighttime terpene concentrations had two maxima near the terpene sources, one in the crown and the other one near the ground. Besides, Petersson (1988) reported very high nighttime concentrations in the air samples collected only several centimeters above the ground in Scots pine forest.

As an important confirmation of the existence of a not considered source of natural VOCs can serve the results of seasonal measurements of terpene concentration in the atmosphere. The autumn maximum of many monoterpene species in the atmosphere was observed by Hakola et al. (2000). Allyear-round measurements (2000-2002) of these compounds above the Finish coniferous forests showed that the autumn (September-November) monoterpene concentrations remained close to the summer (June-July) values (Hakola et al., 2003). Moreover, Hellén et al. (2006) registered the highest hydrocarbon emissions from the Scots pine forest floor not only in autumn, but also in spring. Their comparison with living pine emissions showed that the forest floor may be an important monoterpene source, especially in springtime.

Another contradiction is related to the source of the VOCs emission from the forest floor. In Janson's (1993) opinion, the ground emission could not be explained by sources in the litter alone, and he suggested that the root system of trees is also a source of emission. On the other hand, Hayward et al. (2001) postulated that the monoterpene fluxes to the atmosphere originate mostly from the litter recently fallen on the soil surface. Stepanov's (1999) field measurements corresponded well with this conclusion: monoterpene emissions on two plots in the 80-year-old stand of $P$. abies with dead leaf litter and with the undisturbed bare ground were respectively 149 and $18 \mu \mathrm{g} \mathrm{m}^{-2} \mathrm{~h}^{-1}$.

As can be concluded from the few above-cited observations, leaf litter emits into the atmosphere highly reactive terpenes whose emission rates can vary in a very wide range. The maxima of emissions at relatively low temperatures showed that decomposing plant litter was an important seasonal source of terpenes. This implies that current VOCs emission inventories can be to some degree unreliable, as they omit VOCs fluxes from dead vegetation remains. However, so far the available data set is too small to estimate the actual scale of this phenomenon.

This paper presents the results of preliminary investigation of the changes in chemical composition of pine and spruce litter during their decomposition under natural conditions typical to central Europe. Our aims were: (1) to measure monoterpene emission rates from the needle litters in the first stages of their decomposition, and (2) to record changes in the chemical composition of the extractive organics in the litter which can be potential precursors of volatile organic compounds emitted by the leaf decomposing fungi in the later stages of the process.

\section{Experimental}

\subsection{Materials}

Commercially available $\alpha$-pinene, 3-carene, limonene, $\beta$ caryophyllene, $\alpha$-humulene were purchased from Roth (Warsaw, Poland), whereas hydroquinone and phenolcarboxylic acids: salicylic, anisic, vanillic, gentisic, $p$-coumaric, gallic, ferulic and caffeic, as well as glucose and glucitol, BSTFA with addition of $1 \%$ trimethylchlorosilane were purchased from Sigma-Aldrich (Poznań, Poland). Hexane 
(Baker, HPLC grade), diethyl ether and pyridine (Gliwice, Poland) were used without additional purification. SPME Holder 57330-U with fused silica fibers with PDMS $(100 \mu \mathrm{m})$ and Carboxen/PDMS $(75 \mu \mathrm{m})$ stationary phases were purchased from Supelco Inc. (Bellefonte, PA, USA).

\subsection{Site description}

The study was carried out in the Kopna Góra arboretum belonging to a large complex of Puszcza Knyszyska Forest located $28 \mathrm{~km}$ to the north-east of the Białystok city (northeastern Poland), at $53^{\circ} 14^{\prime} \mathrm{N}$ and $23^{\circ} 29^{\prime} \mathrm{E}$. The forest type is classified as Srratulo-Pinetum W. Mat. 1881. The arboretum is located on a flat area of deep glacifluvial sand sediments at the altitude of $135 \mathrm{~m}$ a.s.l. The mean annual precipitation amounts to $650 \mathrm{~mm}$ (1993-2007), and the mean annual temperature is $6.9^{\circ} \mathrm{C}$. The length of the growing season is about 200 days. The tree layer is composed of Pinus sylvestris and Picea abies with about fifty- to sixty-year-old trees. The bottom layer, completely covering the ground, is composed mainly of the moss Pleurozium schreberi (Brud.) Mitt. and Dicranum polysetum $\mathrm{Sv}$., together with the cowberry Vaccinium vitis-idaea $\mathrm{L}$.

\subsection{Needle litter collection and field incubation}

Light-brown needles from the needle generation to be shed were collected in October 2005 at abscission from pine trees (12-15 trees) growing at the site by shaking the limbs of the trees. The spruce needles were collected from the Norway spruce plantation. For each species of litter, before sample preparation, the gathered material was thoroughly mixed in order to obtain a homogeneous sample. After mixing, a part of the needles sample was used for determination of: dry mass, VOCs emissions and fungal colonization, while the rest of the collected material was dried and stored at room temperature until incubation.

For the incubation, sieve-like litterbags $(200 \times 200 \times$ $20 \mathrm{~mm}$; mesh size of $1.5 \mathrm{~mm}$ ) with terylene net were used; each bag contained $15 \mathrm{~g}$ of litter. Litterbags were fastened to the native litter/moss layer in the two measurement plots $(2.5 \times 2.0 \mathrm{~m})$ beneath pine and spruce trees. The lid cover was constructed of terylene net. The incubation was started on 17 November 2005. Sampling was carried out a couple of times per year, and on each occasion three samples from each plot were collected. The samples were transported to the laboratory and divided into several subsamples to determine: litter mass loss, terpenes emission rate into the gas phase, chemical composition of extractive organic compounds.

To estimate the mass loss, the linear determination method was used (Vizro De Santo et al., 2002). Needles were dried at $105^{\circ} \mathrm{C}$, and five samples of $1 \mathrm{~m}$ of the needles were measured and weighed. The average mass of $1 \mathrm{~m}$ of the "fresh" pine and spruce needles was $0.262 \pm 0.011$ and $0.178 \pm 0.007 \mathrm{~g}$, respectively.

\subsection{Chemical analysis}

\subsubsection{Sampling of monoterpenes and evaluation of their emission rate from needle litter}

Volatile terpenes emitted into the gas phase from litter, were collected by solid-phase microextraction (SPME), and analyzed by means of gas chromatography-mass spectrometry (GC-MS) (Isidorov et al., 2003, 2005). These series of experiments were conducted immediately after the transportation of the litter samples into the laboratory. An amount of the naturally moist needles $(15-20 \mathrm{~g})$ was placed into a glass vessel ( $900 \mathrm{ml}$ volume) which had been previously washed with a 5\% solution of BSTFA in toluene, followed by methanol washing and drying at $80^{\circ} \mathrm{C}$. Later, the vessel was sealed hermetically with a lid supplied with an inlet port, and the rubber septum of the port was immediately picked by a needle protected the SPME fused silica fiber and the fiber coating was exposed to a headspace gas phase for $60-150 \mathrm{~min}$ at the temperature $20 \pm 1^{\circ} \mathrm{C}$. To improve of the sorption conditions, every $15 \mathrm{~min}$ the vessel was intensively shaken causing the gas phase to mix. During this operation, the fused silica fiber was drawn inside the needle of the holder to avoid its breaking. For the quantitative determination of terpenes, a fiber coated with PDMS was used; for qualitative registration of both terpenes and other volatile compounds (such as light hydrocarbons and carbonyls) Carboxen/PDMS coating was used. The adsorbed components were desorbed by introducing the SPME fiber into the injector of GC-MS apparatus with previously calibrated detector.

The quantity of terpene adsorbed on the fiber $\left(m_{\mathrm{f}}^{i}\right)$ was determined from the results of GC-MS analysis. The concentration of individual components in the gas phase of the vessel was calculated from the equation:

$C_{\mathrm{g}}^{i}=m_{\mathrm{f}}^{i} /\left(V_{\mathrm{f}} \times K_{\mathrm{fg}}^{i}\right)$,

where $V_{\mathrm{f}}$ is the volume of the stationary phase of PDMS at a layer thickness $100 \mu \mathrm{ml}(0.690 \mu \mathrm{l})$ and $K_{\mathrm{fg}}^{i}$ is the distribution coefficient for terpene $i$ between air and fiber coating. Experimental and calculated $K_{\mathrm{fg}}$ values for 19 monoterpenes were published previously (Isidorov and Vinogorova, 2005; Isidorov et al., 2005). Terpene emission rate $[\mu \mathrm{g} /(\mathrm{g} \mathrm{h})]$ was calculated from the equation:

$E^{i}=\left(C_{\mathrm{g}}^{i}-C_{\mathrm{g}}^{i o}\right) \times V /(t \times m)$,

where $V$ is the gas phase volume in the vessel, $C_{\mathrm{g}}^{i o}$ is the initial terpene concentration in the gas phase (it was assumed to be equal to zero), $t$ is the litter's residence time in the vessel, $m$ is the litter dry weight.

\subsubsection{Extraction of non-volatile compounds from needles}

Air-dried samples of needles $(5 \mathrm{~g})$ were ground to particles of less than $1 \mathrm{~mm}$ in diameter and, while being constantly 
stirred, were extracted with hexane $(3 \times 50 \mathrm{ml})$ for $1 \mathrm{~h}$ at temperature of $50^{\circ} \mathrm{C}$. Afterwards, the material was successively extracted at room temperature with ether $(3 \times 40 \mathrm{ml})$ and water $(3 \times 30 \mathrm{ml})$ at the temperature of $80^{\circ} \mathrm{C}$. The extracts were filtered through a paper filter. The hexane extract was concentrated on a rotor evaporator to a volume of $1.0 \mathrm{ml}$, and then analyzed by GC-MS. From the ether and water extracts, the solvent was completely removed on the rotor evaporator. The dry residue was washed out (after its mass had been determined) by the $2 \mathrm{ml}$ of ether or methanol, and $0.2-0.5 \mathrm{ml}$ of this solution (ca. $15 \mathrm{mg}$ of dry residue) was put into a vial of $2 \mathrm{ml}$ volume. After subsequent evaporation of solvent, $220 \mu \mathrm{l}$ of pyridine and $80 \mu \mathrm{l}$ of BSTFA were added. The reaction mixture was sealed and heated for $0.5 \mathrm{~h}$ at $60^{\circ} \mathrm{C}$ to obtain trimethylsilyl (TMS) derivatives of polar compounds. The whole procedure was performed in triplicate.

\subsubsection{GC-MS analysis}

The separation of components was performed on a HP 6890 gas chromatograph with a mass selective detector MSD 5973 (Agilent Technologies, USA). This device was equipped with a HP- $5 \mathrm{~ms}$ fused silica column $(30 \mathrm{~m} \times 0.25 \mathrm{~mm}$ i.d., $0.25 \mu \mathrm{m}$ film thickness). Helium flow rate through the column was $1 \mathrm{ml} \mathrm{min}{ }^{-1}$. The EIMS spectra were obtained at $70 \mathrm{eV}$ of ionization energy. Detection was performed in the full scan mode from 41 to 600 a.m.u. After integration, the fraction of each component in the total ion current (TIC) was calculated. The components were identified with the aid of an automatic system of GC-MS data processing supplied by NIST mass spectra library.

The compounds concentrated by SPME were desorbed by introducing for $15 \mathrm{~min}$ the fiber into the injector of gas the chromatograph working in splitless mode. The initial thermostat temperature was $35^{\circ} \mathrm{C}(5 \mathrm{~min})$; later, it was increased to $250^{\circ} \mathrm{C}$ at the rate of $3^{\circ} \mathrm{C} \mathrm{min}^{-1}$. Hexane extracts and TMS derivatives were separated in the linear temperature programmed regime from 40 to $300^{\circ} \mathrm{C}$ at the rate $3^{\circ} \mathrm{C} \mathrm{min}^{-1}$ (split 1:10).

Hexane solutions of $\mathrm{C}_{5}-\mathrm{C}_{18}$ or $\mathrm{C}_{10}-\mathrm{C}_{40} n$-alkanes were separated under above conditions. The values of retention times of $n$-alkanes and analytes were employed to calculate the linear temperature programmed retention indices (LTPRI). To enhance the reliability of identification, we used both mass spectra library search and LTPRI of registered chromatographic peaks. An in-house developed computer program was used to identify LTPRI values. It makes use of a database with LTPRI values more than 6500 organic compounds obtained from literature and measurements in our laboratory. Identification was considered reliable if the results of computer search at the MS library were confirmed by the measured LTPRI, the deviation of which from the database values did not exceed \pm 5 u.i.

To calibrate the MSD, the series of six solutions of listed in the Sect. 2.1 terpenes, phenolcarboxylic acids (PCA), and carbohydrate compounds in hexane or methanol covering the concentration range $10-2000 \mathrm{mg} \mathrm{l}^{-1}$ was prepared. $1 \mathrm{ml}$ of the PCA or carbohydrate compounds calibration solution was transferred to a vial of $2 \mathrm{ml}$ volume. After evaporation of methanol, $220 \mu \mathrm{l}$ of pyridine and $80 \mu \mathrm{l}$ of BSTFA were added into the vial, and the content was heated at $60^{\circ} \mathrm{C}$ for $0.5 \mathrm{~h}$. Hexane solutions and TMS derivatives were subjected to GC-MS analysis in the conditions described above. On the basis of the analysis results, regression equations were formulated. The calibration procedure was carried out at each of the needle litter collections.

\section{Results and discussion}

Two groups of factors controlling changes of leaf litter's chemical composition during its decomposition can be distinguished: abiotic and biotic. Abiotic factors include evaporation of VOCs, mechanical destruction caused by the freeze-thaw wounding (Fall et al., 2001), photo- and thermochemical oxidation (Warneke et al., 1999), and leaching of water-soluble compounds. As for biotic factors, they include action of saprotrophs (microorganisms, invertebrates, and vertebrates inhabiting litter and upper soil layers), as well as soil-enzyme reactions (Cox et al., 2001; Fioretto et al., 2007). It can be assumed that the emission of secondary metabolites (such as terpenes) from litter into the atmosphere depends chiefly on abiotic factors. However, biological processes can be a source of volatile "tertiary" metabolites such as lower alcohols, carbonyls, esters, etc. (Isidorov et al., 2003; Leff and Fierer, 2008). Up to the present, the regularities in the relationship between various abiotic and biotic factors have not been discovered.

\subsection{Emission of VOCs from pine and spruce needle litter}

In the course of the experiment, we identified with HSSPME/GC-MS more than $80 \mathrm{C}_{2}-\mathrm{C}_{15}$ compounds in the volatiles emitted from pine and spruce needle litter. The complete list of identified compounds and their relative fraction (in \% of TIC) is presented in Table 1S in Supplementary information in the WEB-edition of the Journal. This list includes among others 25 monoterpene and 23 sesquiterpene compounds, 13 carbonyls and 5 esters.

Table 1 contains the emission rates of six monoterpenes determined at $20^{\circ} \mathrm{C}$. For comparison, the last column of the table presents determined earlier emission rate of monoterpenes from European larch needle litter. It should be noticed that the highest emission rates from pine and spruce litter were observed in the first stages of decomposition (Isidorov et al., 2005). During the first six months of experiment the emission rate had the same order of magnitude as the emission rate from living needles of trees of these species. According to data cited in the review article by 
Table 1. Emission rate of monoterpene hydrocarbons from leaf litter of Scots pine and Norway spruce $\left(20^{\circ} \mathrm{C}\right)$.

\begin{tabular}{|c|c|c|c|c|c|c|c|c|c|c|c|}
\hline \multirow[t]{3}{*}{ Terpene } & \multicolumn{10}{|c|}{ Emission rates $\left[\mu \mathrm{g} \times\left(\mathrm{g} \times \mathrm{h}^{-1}\right), \mathrm{dw}\right]$ vs. decomposition time (days) } & \multirow{3}{*}{$\begin{array}{c}\text { Larch } \\
\text { litter* } \\
0\end{array}$} \\
\hline & \multicolumn{5}{|c|}{ Pine litter } & \multicolumn{5}{|c|}{ Spruce litter } & \\
\hline & 0 & 77 & 165 & 282 & 490 & 0 & 77 & 165 & 282 & 490 & \\
\hline$\alpha$-Pinene & 1.15 & 5.13 & 1.01 & 0.18 & 0.06 & 0.06 & 0.56 & 0.44 & 0.16 & 0.09 & 0.50 \\
\hline$\beta$-Pinene & 0.09 & 0.24 & 0.04 & 0.01 & trace & 0.02 & 0.07 & 0.06 & trace & trace & 0.18 \\
\hline Camphene & 0.18 & 0.47 & 0.15 & 0.03 & 0.04 & 0.10 & 0.63 & 0.76 & 0.28 & 0.10 & 0.10 \\
\hline 3-Carene & 0.53 & 1.65 & 0.42 & 0.10 & 0.10 & - & 0.03 & 0.02 & 0.02 & trace & - \\
\hline Limonene & 0.01 & 0.03 & 0.02 & trace & trace & 0.02 & 0.16 & trace & 0.05 & 0.02 & 0.11 \\
\hline Terpinolene & 0.01 & 0.02 & - & - & - & - & 0.01 & - & - & - & - \\
\hline Myrcene & - & - & - & - & - & - & - & - & - & - & 0.05 \\
\hline$\beta$-Phellandrene & - & - & - & - & - & - & - & - & - & - & 0.12 \\
\hline Total & 1.96 & 7.54 & 1.64 & 0.32 & 0.20 & 0.20 & 1.46 & 1.28 & 0.51 & 0.21 & 1.08 \\
\hline
\end{tabular}

* Emission rate at $22^{\circ} \mathrm{C}$ from fresh litter of European larch, Larix decidue; (Isidorov et al., 2005).

Kesselmeier and Staudt (1999), emission rates from living needles of $P$. sylvestris and $P$. abies are within the ranges of $0.8-12.1$ and $0.2-7.8 \mu \mathrm{g} /(\mathrm{g} \mathrm{h})$, respectively. In later stages of the experiment a decline in terpenes emission rate was observed; however, after about 1.5 year the rate was still noticeable. Such a long-time terpene emission indicates that the litter retained these secondary metabolites for a long period.

It cannot be excluded that terpene emission on the latter stages of decomposition is maintained also by litter decomposing fungi such as ascomycetes (Penicillum sp.), phycomycetes (Mucor sp.) and basidiomycetes (Trichoderma sp.). In the volatiles emitted by 15 species of fungi belonging to these genera isolated from pine and spruce litter in the course of the experiment, all eight monoterpenes reported in Table 1 were identified (unpublished data). These data correspond with the observations by Nilsson et al. (1996) who detected the series of mono- and sesquiterpenes in volatiles emitted from litter-destroying fungi of the genus Penicillum (cultures were grown on yeast extract sucrose agar which does not contain of terpenes).

Besides, the appearance in the emissions (in the course of litter incubation) of new compounds (such as ethanol, esters, acetone and other carbonyls) proved the occurrence of biochemical processes involving carbohydrates which had been originally present in the litter, or had appeared during the process of cellulose and ligno-cellulose complexes decomposition (Leff and Fierer, 2008).

\subsection{Changes in extractive substances composition over time}

\subsubsection{The mass loss and fractional composition of extracts}

After 165 days of incubation, the mass loss of pine and spruce needle litter was about $16 \%$ and $13 \%$ respectively, whereas at the end of experiment (i.e. after 490 days) the accumulated mass loss reached $20 \%$ and $17 \%$ respectively. Thus, the greatest mass loss occurred during the initial six months of decomposition. According to Kainulainen and Hopolainen (2002), the accumulated mass loss for $P$. sylvestris needles in a pine forest growing in central Finland amounted to about $22 \%$ after 594 days of decomposition. Therefore, from the comparison of these two results it seems that in the milder climatic conditions of Poland, the mass loss of pine litter proceeds slightly faster than in Finland (where winters are longer and snow cover is thicker).

The first section of Table 2 presents changes in the fractional composition of extracted compounds of the needle litters. As can be seen, the total content of extracted compounds was decreasing in the course of the decomposition; however, this level of decrease was not identical for different fractions. While on each of the stages of the experiment a steady decrease in water-soluble components could be observed, the content of compounds extracted from pine litter with hexane and ether had been increasing until the 77th day, and only decreased relatively slowly after that. Nonetheless, in the case of spruce litter, this initial increase in hexaneextractive fraction was not observed.

Moreover, the first months of decomposition witnessed also the increase of the mass of ether-soluble fractions in both pine and spruce needles. This phenomenon was only partly linked with the appearance of new compounds in 
Table 2. Changes of the fractional composition of extracts and mean concentrations $\left[\mu \mathrm{g}^{-1}(\mathrm{dw})\right]$ of selected compounds in decomposing Scots pine and Norway spruce needles.

\begin{tabular}{|c|c|c|c|c|c|c|c|c|c|c|}
\hline \multirow[t]{2}{*}{ Extract/compound } & \multicolumn{5}{|c|}{ Pine litter } & \multicolumn{5}{|c|}{ Spruce litter } \\
\hline & 0 & 77 & 165 & 282 & 490 & 0 & 77 & 165 & 282 & 490 \\
\hline \multicolumn{11}{|c|}{ Mass of fraction vs. decomposition time (days) } \\
\hline Hexane & 56.8 & 89.5 & 73.8 & 65.8 & 48.1 & 57.8 & 48.5 & 30.0 & 30.2 & 28.1 \\
\hline Ether & 16.2 & 17.6 & 17.0 & 16.6 & 15.6 & 6.0 & 10.4 & 8.9 & 13.1 & 10.5 \\
\hline Water & 80.0 & 42.5 & 27.6 & 19.0 & 17.0 & 72.0 & 55.7 & 29.2 & 20.1 & 20.5 \\
\hline Total & 153.0 & 149.6 & 118.4 & 98.1 & 80.7 & 135.8 & 114.6 & 68.1 & 63.4 & 59.1 \\
\hline \multicolumn{11}{|c|}{ Monoterpene hydrocarbons in hexane extracts } \\
\hline Tricyclene & n.d. ${ }^{1}$ & 47 & 34 & 33 & 11 & 16 & 14 & 4 & 6 & $\operatorname{trace}^{2}$ \\
\hline$\alpha$-Thujene & n.d. & 24 & 52 & 50 & 26 & 2 & 8 & 2 & n.d. & n.d. \\
\hline$\alpha$-Pinene & 1038 & 1170 & 663 & 430 & 218 & 81 & 51 & 20 & 18 & 16 \\
\hline Camphene & 152 & 131 & 217 & 95 & 81 & 155 & 106 & 36 & 41 & 32 \\
\hline$\alpha$-Fenchene & n.d. & n.d. & 25 & n.d. & n.d. & n.d. & n.d. & n.d. & n.d. & n.d. \\
\hline Sabinene & 28 & 13 & 52 & 29 & 18 & 16 & 12 & 3 & trace & n.d. \\
\hline$\beta$-Pinene & 122 & 100 & 64 & 57 & 11 & 16 & 1 & 5 & 5 & 5 \\
\hline Myrcene & 56 & 23 & 17 & 3 & trace & 43 & 18 & 8 & 7 & 5 \\
\hline 3-Carene & 940 & 824 & 592 & 116 & 94 & 8 & 5 & 1 & 2 & 1 \\
\hline$\alpha-$ Terpinene & 8 & 10 & 80 & 38 & 13 & 2 & 3 & 0.5 & trace & trace \\
\hline Limonene & 59 & 61 & 38 & 38 & 30 & 154 & 62 & 29 & 25 & 22 \\
\hline$\beta(\mathrm{Z})$-Ocimene & 10 & 16 & 5 & n.d. & n.d. & n.d. & n.d. & 0.5 & n.d. & n.d. \\
\hline$\beta(\mathrm{E})$-Ocimene & 33 & n.d. & n.d. & n.d. & n.d. & n.d. & n.d. & n.d. & n.d. & n.d. \\
\hline$\gamma$-Terpinene & 19 & 20 & 24 & 9 & 6 & 4 & 8 & 1 & 1 & trace \\
\hline Terpinolene & 68 & 36 & 25 & 9 & 7 & 6 & n.d. & 1 & 2 & trace \\
\hline Total & 2533 & 2475 & 1888 & 912 & 515 & 503 & 298 & 113 & 107 & 81 \\
\hline
\end{tabular}

Sesquiterpene hydrocarbons in hexane extracts

\begin{tabular}{|c|c|c|c|c|c|c|c|c|c|c|}
\hline$\delta$-Elemene & 99 & - & - & - & - & - & - & - & - & - \\
\hline$\alpha$-Cubebene & 116 & - & - & - & - & - & - & - & - & - \\
\hline Ylangene & 12 & - & - & - & - & - & - & - & - & - \\
\hline$\alpha$-Copaene & 120 & - & - & - & - & 6 & - & - & - & - \\
\hline$\beta$-Cubebene & 112 & - & - & - & - & - & - & - & - & - \\
\hline$\beta$-Elemene & 101 & - & - & - & - & - & - & - & - & - \\
\hline Isolongifolene & 26 & - & - & - & - & - & - & - & - & - \\
\hline$\beta$-Caryophyllene & 583 & - & - & - & - & 32 & - & - & - & - \\
\hline Aromadendrene & 136 & - & - & - & - & - & - & - & - & - \\
\hline$\alpha$-Humulene & 92 & - & - & - & - & - & - & - & - & - \\
\hline$\gamma$-Muurolene & 408 & - & - & - & - & 6 & - & - & - & - \\
\hline Germacrene D & 245 & - & - & - & - & 19 & - & - & - & - \\
\hline$\beta$-Selinene & 284 & - & - & - & - & - & - & - & - & - \\
\hline$\alpha$-Selinene & 717 & - & - & - & - & - & - & - & - & - \\
\hline$\alpha$-Muurolene & 245 & - & - & - & - & 7 & - & - & - & - \\
\hline$\gamma$-Cadinene & 1366 & - & - & - & - & 43 & - & - & - & - \\
\hline$\alpha$-Cadinene & 102 & - & - & - & - & - & - & - & - & - \\
\hline$\alpha$-Calacorene & 31 & - & - & - & - & - & - & - & - & - \\
\hline Total & 4795 & - & - & - & - & 113 & - & - & - & - \\
\hline \multicolumn{11}{|c|}{ Phenols in ether extracts } \\
\hline Hydroquinone & n.d. & 2 & 1 & n.d. & n.d. & n.d. & 1 & 2 & n.d. & n.d. \\
\hline Vanillic acid & 2 & 4 & 6 & 9 & 21 & 1 & 4 & 6 & 43 & 64 \\
\hline 4-Hydroxy benzoic acid & 2 & 5 & 6 & 8 & 5 & 1 & 5 & 5 & 5 & 4 \\
\hline$p$-Coumaric acid & 4 & 8 & 14 & 24 & 39 & 3 & 11 & 21 & 32 & 43 \\
\hline Ferulic acid & 5 & n.d. & n.d. & 57 & 77 & 3 & 24 & 36 & 46 & 51 \\
\hline Caffeic acid & 3 & n.d. & n.d. & 32 & 49 & n.d. & n.d. & n.d. & 13 & 24 \\
\hline Total phenols & 16 & 19 & 27 & 130 & 191 & 8 & 45 & 70 & 139 & 186 \\
\hline
\end{tabular}


Table 2. Continued.

\begin{tabular}{|c|c|c|c|c|c|c|c|c|c|c|}
\hline \multirow[t]{2}{*}{ Extract/compound } & \multicolumn{5}{|c|}{ Pine litter } & \multicolumn{5}{|c|}{ Spruce litter } \\
\hline & 0 & 77 & 165 & 282 & 490 & 0 & 77 & 165 & 282 & 490 \\
\hline \multicolumn{11}{|c|}{ Carbohydrate compounds in water extracts } \\
\hline Xylose & trace & 4 & trace & trace & 0.2 & trace & 10 & 1 & trace & trace \\
\hline Arabinose & trace & 3 & 1 & n.d. & trace & trace & 11 & 5 & trace & trace \\
\hline Mannose & trace & 2 & n.d. & trace & n.d. & 892 & 76 & n.d. & n.d. & n.d. \\
\hline Galactose & trace & trace & 1 & trace & 2 & trace & 13 & 3 & trace & 10 \\
\hline$\alpha$-Fructofuranose & 428 & n.d. & trace & n.d. & n.d. & trace & n.d. & n.d. & n.d. & n.d. \\
\hline$\beta$-Fructofuranose & 353 & n.d. & n.d. & n.d & n.d. & trace & n.d. & n.d. & n.d. & n.d. \\
\hline$\alpha$-Glucopyranose & 1516 & 33 & 23 & 21 & 108 & 1008 & 120 & 32 & 28 & 199 \\
\hline$\beta$-Glucopyranose & 1665 & 8 & 25 & 21 & 104 & 1138 & 147 & 37 & 30 & 205 \\
\hline Trehalose & trace & 13 & 50 & 62 & 69 & 125 & 105 & 132 & 124 & 131 \\
\hline Arabinitol & 3805 & trace & 22 & 11 & 1 & 5730 & 138 & 65 & 12 & trace \\
\hline Glucitol & 1387 & trace & 65 & 49 & 80 & 2736 & 168 & 130 & 44 & 24 \\
\hline myo-Inositol & 4485 & trace & trace & trace & 1 & 1929 & 108 & trace & n.d. & n.d. \\
\hline Total carbohydrates & 13639 & 63 & 187 & 164 & 365 & 13588 & 896 & 411 & 238 & 569 \\
\hline
\end{tabular}

Note: n.d. - not detected; trace - below $0.2 \mu \mathrm{g} \mathrm{g}^{-1}$.

the corresponding fractions (for instance, sesquiterpene and diterpene alcohols and lipids, which were practically non existent in "fresh" litter), or with increasing contents of microbal sterols. The main contribution to the observed increase of hexane extracts was made by the compounds which were not identified: after 77 days of decomposition, the fraction of non-identified substances increased almost 1.5 times compared with fresh litter, amounting to $41.4 \%$ of TIC.

\subsubsection{Chemical composition of extracts}

This section discusses the changes in fractional composition of the decomposed needle litters, and presents the results of quantification of selected compounds for which regression equations were formulated. The complete list of compounds identified in separate fractions is presented in Tables $2 \mathrm{~S}-4 \mathrm{~S}$ in Supplementary information.

\section{Hexane extracts}

contained more than 200 compounds whose content was more than $0.1 \%$ of TIC. In the highest quantities were terpenes $\mathrm{C}_{10} \mathrm{H}_{16}, \mathrm{C}_{15} \mathrm{H}_{24}$ and $\mathrm{C}_{20} \mathrm{H}_{32}$, hydrocarbons, and their oxygenated derivatives. In the course of decomposition progressive decreasing of volatile monoterpenes content was observed, the quantitative composition of which is presented in the second section of Table 2. After 16-month decomposition their content in the pine and spruce litter decreased over 5 and 7 times respectively; however, the total concentration of terpenes was still rather high. These data correspond well with observations by Kainulainen and Hopolainen (2002) who noted that after seven-month decomposition of Scots pine litter, concentration of 10 monoterpenes decreased over $60 \%$ in relation to the initial concentration. These authors reported the presence of four sesquiterpene hydrocarbons in pine litter. In the present experiment, the quantitative analysis of sesquiterpenes was carried out on initial samples only. Nonetheless, according to our observations, their content was considerable on all of the stages of pine litter decomposition, amounting to $20-30 \%$ of TIC on chromatograms of hexane extracts from pine litter. Spruce litter was much poorer in $\mathrm{C}_{15} \mathrm{H}_{24}$ hydrocarbons, and in hexane extracts $\mathrm{C}_{20} \mathrm{H}_{32}$ hydrocarbons were the principal terpenes (18-29\% of TIC). Oxygenated mono- and sesquiterpenes were disappearing quicker than hydrocarbons: after 6-month decomposition, the content of the former in pine litter decreased twice, while the amount of lost monoterpenes was about $25 \%$. The same difference in the loss of terpenes and their O-derivatives from the leaf litter of Umbellularia californica was observed by Wood et al. (1995).

Non-volatile components of hexane extracts included also sterols whose relative composition changed quickly in the first stages of the decomposition. Extract from fresh pine litter contained only $\beta$-sitosterol (1.7\% of TIC), but after 2.5 months 7 different sterols were identified and their relative content rose to $9.8 \%$ of TIC. In the spruce litter the content of sterols after 2.5 months increased from 19 to $27 \%$. The increase of sterols content in the needle litter during decomposition might occur due to the increase of fungal biomass (Berg and Söderström, 1979; Vizro De Santo et al., 2002) as well as due to the enzymatic hydrolysis of esterified and glycosylated sterols of plant origin (Toivo et al., 2000).

\section{Ether extracts}

contain presumably medium polar compounds. The total list of compounds registered on the chromatograms of these extracts includes 180 substances belonging to different classes, 
mainly of acidic character. The principal components of ether extracts in all of the stages of pine and spruce needles decomposition were aliphatic fatty acids and diterpene resin acids. Among the former palmitic, linoleic, and oleic acids were the dominant compounds; dehydroabietic acid was the main resin acid in the both types of needle litter during the whole experiment, and this observation conforms to data presented by Kainulainen and Hopolainen (2002).

In our investigation we analyzed quantitatively only six compounds whose concentrations and changes are presented in the third section of Table 2. All these compounds belong to the plant metabolites family. Besides, they are components of structural plant polymers such as ligno-cellulose and lignin. Substantial growth of their concentrations in the final stages of our experiment can be explained by the beginning of the decomposition of these recalcitrant polymers by the fungi colonizing the litter. It was established that the most significant group of saprophytes able to carry out lignin degradation are basidiomycetes (Kjøller and Struwe, 1987; Cox et al., 2001). Lignolytic basidiomycetes can be detected in the Scots pine litter after 3-12 months of incubation, and their colonization starting time conditioned fundamentally by the availability of water (Cox et al., 2001; Vizro De Santo et al., 2002). Apparently, small amounts of vanillin, 3-vanilpropanol, 4-hydroxy benzaldehyde, 4-hydroxy acetophenone, as well as lignan matairesinol which were detected in ether extracts were also products of lignin decomposition. The content of the last compound (matairesinol) in the extracts from pine and spruce litter amounted to 6.510.0 and $2.6-5.2 \%$ of TIC respectively.

\section{Water extracts}

were more variable in their composition: the total quantity of these fractions decreased about $60-65 \%$ during the first six month (Table 2). The final section of Table 2 shows that these abrupt changes were related to a drastic decrease of carbohydrates and polyols. However, in the late stages of decomposition, the content of the former increased to a certain extent, particularly taking into account glucose and a disaccharide trehalose. The appearance of these compounds can be explained by the action of saprophytes decomposing lignocellulose complexes of the plant remains. Relatively high concentration of trehalose in "fresh" spruce needles may indicate that collected by us material had been already colonized by fungi.

During the middle stages of decomposition, several products of carbohydrate oxidation were found in water extracts, specifically: arabinoic, glucaric, gluconic, galactaric, glucuronic, and galactonic acids. Apart from carbohydrates, water extracts contained many other polar compounds, such as phosphoric acid, glycerol, as well as malic, shikimic, and citric acids. After 2.5 months of decomposition, nitrogencontaining compounds, including 13 aminoacids, thymine, uridine, and adenine, were found in all extracts, and they constituted over $10-15 \%$ of TIC.

\section{Conclusions}

Unlike the case of VOCs emission from living terrestrial vegetation, there is only little knowledge about such emission from leaf litter into the atmosphere. Not much is also known about the composition of non-volatile organic compounds in decaying litter that can exert influence on soil environment.

Although with the two analyzed within this study types of leaf litter the data set is too small to estimate reliably the scale of either VOCs emission or migration of water-soluble organics into the soil, some preliminary notes can be made:

1. The entirety of the presented data proves that decomposed Scots pine and Norway spruce litter can emit volatile terpenes into the gas phase with the rates comparable to the emission rates of living needle leafs only in the first stages of decomposition. However, taking into account the constant inflow and renovation of the leaf litter (according to our estimation, the annual litter mass flow in Polish forests lays in the range 16$19 \mathrm{Mt} \mathrm{yr}^{-1}$ ), it can be supposed that the forest floor is an important source of atmospheric terpenes. Long-term existence of a relatively high rate of terpene emission (at least in the first 1.5 years of decomposition in the middle latitude climatic conditions) is related to a rather high reserve of these compounds in decaying litter, and (supposedly) vital activity of litter-destroying fungi.

2. Leaf litter emits not only monoterpenes, but also many other VOCs such as lower carbonyls, alcohols, esters and chloro-containing compounds, all of which actively participate in atmospheric processes (Atkinson, 2000). Fallen leaves contain considerable amounts of organic material that can serve as a precursor of volatile oxygenated VOCs formed in the course of enzymatic (fungal) decomposition. Emission into the gas phase of wide spectra of oxygenated compounds was demonstrated by the example of isolates of most frequently encountered species of needle litter decomposing fungi (Nilsson et al., 1996; Isidorov et al., 2009).

3. Leaf litter is an important source of various organics which perform important biochemical and ecological functions in soils. Non-volatile, but much better soluble in water oxygenated terpenoids, aliphatic and resin acids, carbohydrates and phenolic products of decomposition of ligno-cellulose complexes may be involved in nutrient cycling and have no small influence on the structure of rhizosphere (Cox et al., 2001; Fioretto et al., 2007). 
Hence, there is a clear need for further investigation of the chemical composition of VOCs and extractive compounds in the leaf litter of other trees and in other climatic conditions.

\section{Supplementary material related to this article is available online at: \\ http://www.biogeosciences.net/7/2785/2010/ \\ bg-7-2785-2010-supplement.pdf.}

Acknowledgements. This study has been supported by the Ministry of Science of Poland by grant N305 067 32/2411.

Edited by: W. Otten

\section{References}

Atkinson, R.: Atmospheric chemistry of VOCs and $\mathrm{NO}_{\mathrm{x}}$, Atmos. Environ., 34, 2063-2101, 2000.

Berg, B. and Söderström, B.: Fungal biomass and nitrogen in decomposing Scots pine litter, Soil Biol. Biochem., 11, 339-341, 1979.

Cox, P., Wilkinson, S. P., and Anderson, J. M.: Effects of fungal inocula on the decomposition of lignin and structural polysaccharides in Pinus sylvestris litter, Biol. Fert. Soils, 33, 246-251, 2001.

Curci, G., Beekmann, M., Vautard, R., Smiatek, G., Steinbrecher, R., Theloke, J., and Friedrich, R.: Modelling study of the impact of isoprene and terpene biogenic emissions on European ozone levels, Atmos. Environ., 43, 1444-1455, 2009.

Fall, R., Karl, T., Jordan, A., and Lindinger, W.: Biogenic C5 VOCs: release from leaves after freeze-thaw wounding and occurrence in air at a high mountain observatory, Atmos. Environ., 35, 3905-3916, 2001.

Fioretto, A., Papa, S., Pellegrino, A., and Fuggi, A.: Decomposition dynamics of Myrtus communis and Quercus ilex leaf litter: Mass loss, microbal activity and quality change, Appl. Soil Ecol., 36, 32-40, 2007.

Griffin, R., Cocker, D., Seinfeld, J., and Dabdub, D.: Estimate of global atmospheric organic aerosol from oxidation of biogenic hydrocarbons, Geophys. Res. Lett., 26, 2721-2724, 1999.

Guenther, A., Hewitt, C., Erickson, D., Fall, R., Geron, C., Graedel, T., Harley, P., Klinger, L., Lerdau, M., McKay, W., Pierce, T., Scholes, B., Steinbrecher, R., Tallamraju, R., Tailor, J., and Zimmerman, P.: A global model of natural volatile organic compound emissions, J. Geophys. Res., 100, 8873-8892, 1995.

Guenther, A., Geron, C., Pirce, T., Lamb, B., Harley, P., and Fall, R.: Natural emissions of non-methane volatile organic compounds, carbon monoxide, and oxides of nitrogen from North America, Atmos. Environ., 34, 2205-2230, 2000.

Guenther, A.: The contribution of reactive carbon emissions from vegetation to the carbon balance of terrestrial ecosystems, Chemosphere, 49, 837-844, 2002.

Hakola, H., Laurila, T., Rinne, J., and Puhto, K.: The ambient concentrations of biogenic hydrocarbons at a Northern European, boreal site, Atmos. Environ., 34, 4971-4982, 2000.

Hakola, H., Tarvainen, V., Laurila, T., Hultunen, V., Hellén, H., and Keronen, P.: Seasonal variation of VOC concentrations above a boreal coniferous forest, Atmos. Environ., 37, 1623-1634, 2003.
Hayward, S., Muncey, R. J., James, A. E., Halsall, C. J., and Hewitt, C. N.: Monoterpene emissions from soil in Sitka spruce forest, Atmos. Environ., 35, 4081-4087, 2001.

Hellén, H., Hakola, H., Pystynen, K.-H., Rinne, J., and Haapanala, S.: $\mathrm{C}_{2}-\mathrm{C}_{10}$ hydrocarbon emissions from a boreal wetland and forest floor, Biogeosciences, 3, 167-174, doi:10.5194/bg-3-1672006, 2006.

Hoffmann, T., Odum, J., Bowman, F., Collins, D., Klockow, D., Flagan, R., and Seinfeld, J.: Formation of organic aerosols from the oxidation of biogenic hydrocarbons, J. Atmos. Chem., 26, 189-222, 1997.

Isidorov, V. A.: Organic Chemistry of the Earth's Atmosphere, Springer, Berlin, 1990.

Isidorov, V., Povarov, V., and Stepanov, A.: Forest soil cover: VOC sink or source?, in: Proceedings of EUROTRAC Symposium '98, edited by: Borrell, P. M. and Borrel, P., WITpress, Southampton, 158-162, 1999.

Isidorov, V. A., Jaroszynska, J., Sacharewich, T., and Piroznikow, E.: Natural VOC emissions from forests in Poland, Atmos. Environ., 33, 4739-4744, 1999.

Isidorov, V. and Jdanova, M.: Volatile organic compounds from leaves litter, Chemosphere, 48, 975-979, 2002.

Isidorov, V. A., Vinogorova, V. T., and Rafałowski, K.: HS-SPME analysis of volatile organic compounds of coniferous needle litter, Atmos. Environ., 37, 4645-4650, 2003.

Isidorov, V., Vinogorova, V., and Rafałowski, K.: Gas chromatographic determination of extractable compound composition and emission rate of volatile terpenes from larch needle litter, J. Atmos. Chem., 50, 263-278, 2005.

Isidorov, V. A. and Vinogorova, V. T.: Experimental determination and calculation of distribution coefficients between air and fiber with polydimethylsiloxane coating for some groups of organic compounds, J. Chromatogr. A, 1077, 195-201, 2005.

Isidorov, V., Smolewska, M., and Tyszkiewicz, Z.: VOC emission into the atmosphere by trees and leaf litter in Polish forests, Geophys. Res. Abstr., Vol. 11, EGU2009-8510, Vienna, 2009.

Janson, R.: Monoterpene concentrations in and above a forest of Scots pine, J. Atmos. Chem., 14, 385-394, 1992.

Janson, R. W.: Monoterpene emissions from Scots pine and Norwegian spruce, J. Geophys. Res., 98, 2839-2850, 1993.

Janson, R., De Serves, C., and Romero, R.: Emission of isoprene and carbonyl compounds from a boreal forest and wetland in Sweden, Agr. Forest Meteorol., 98-99, 671-681, 1999.

Kainulainen, P. and Holopainen, J. K.: Concentration of secondary compounds in Scots pine needles at different stages of decomposition, Soil Biol. Biochem., 34, 37-42, 2002.

Kang, D., Aneja, V. P., Mathur, M., and Ray, J. D.: Nonmethane hydrocarbons and ozone in three rural south-east United States national parks: a model sensitivity analysis and comparison to measurements, J. Geophys. Res., 108, 4604-4610, 2003.

Kesselmaier, J. and Staudt, M.: Biogenic volatile organic compounds (VOC): an overview on emission, physiology and ecology, J. Atmos. Chem., 33, 23-88, 1999.

Kjøller, A. and Struwe, S.: Functional groups of microfungi on decomposing ash litter, Pedobiologia, 30, 151-160, 1987.

Kulmala, M., Suni, T., Lehtinen, K. E. J., Dal Maso, M., Boy, M., Reissell, A., Rannik, Ü., Aalto, P., Keronen, P., Hakola, H., Bäck, J., Hoffmann, T., Vesala, T., and Hari, P.: A new feedback mechanism linking forests, aerosols, and climate, Atmos. Chem. 
Phys., 4, 557-562, doi:10.5194/acp-4-557-2004, 2004.

Leff, J. W. and Fierer, N.: Volatile organic compound (VOC) emission from soil and litter samples, Soil Biol. Biochem., 40, 16291636, 2008.

Lindfors, V. and Laurila, T.: Biogenic volatile organic compound (VOC) emissions from forests in Finlandia, Boreal Environ. Res., 5, 95-113, 2000.

Nilsson, T., Larsen, T. O., Montanarella, L., and Madsen, J. Ø.: Application of head-space solid-phase microextraction for the analysis of volatile metabolites emitted by Penicillum species, J. Microbiol. Meth., 25, 245-255, 1996.

Petersson, G.: High ambient concentrations of monoterpenes in Scandinavian pine forests, Atmos. Environ., 22, 2617-2619, 1988.

Seinfeld, J. H. and Pankow, J. N.: Organic atmospheric particulate material, Ann. Rev. Phys. Chem., 54, 121-140, 2003.

Simpson, D., Winiwarter, W., Börjesson, G., Cinderby, S., Ferreiro, A., Guenther, A., Hewitt, C. N., Janson, R., Khalil, M. A. K., Owen, S., Pierce, T. E., Puxbaum, H., Shearer, M., Skiba, U., Steinbrecher, R., Tarrasón, L., and Öquist, M. G.: Inventorying emissions from nature in Europe, J. Geophys. Res., 104, 81138152, 1999.

Smiatek, G. and Steinbrecher, R.: Temporal and spatial variation of forest VOC emissions in Germany in the decade 1994-2003, Atmos. Environ., 40, S166-S177, 2006.

Solmon, F., Sarrat, C., Serça, D., Tulet, P., and Rosset, R.: Isoprene and monoterpenes biogenic emissions in France: modeling and impact during a regional pollution episode, Atmos. Environ., 38, 3853-3865, 2004.
Steinbrecher, R., Smiatek, G., Köble, R., Seufert, G., Theloke, J., Hauff, K., Ciccioli, P., Vautard, R., and Curci, G.: Intra- and inter-annual variability of VOC emissions from natural and seminatural vegetation in Europe and neighbouring countries, Atmos. Environ., 43, 1380-1391, 2009.

Stepanov, A. A.: Concentration of phytogenic volatile organic compounds under the canopy of boreal forests, Ph.D. thesis, StPetersburg University, Russia, 1999.

Toivo, J., Lampi, A.-M., Aalto, S., and Piironen, V.: Factors affecting sample preparation in the gas chromatographic determination of plant sterols in whole wheat flour, Food Chem., 68, 239-245, 2000.

Virzo De Santo, A., Rutigliano, F. A., Berg, B., Fioretto, A., Puppi, G., and Alfani, A.: Fungal mycelium and decomposition of needle litter in three contrasting coniferous forests, Acta Oecol., 23, 247-259, 2002.

Warneke, C., Karl, T., Judmaier, H., Hansel, A., Jordan, A., Lindinger, W., and Crutzen, P. J.: Acetone, methanol, and other partially oxidized volatile organic emissions from dead plant matter by abiological processes: Significance for atmospheric $\mathrm{HO}_{\mathrm{x}}$ chemistry, Global Biogeochem. Cy., 13, 9-17, 1999.

Wood, S. E., Gaskin, J. F., and Langenheim, J. H.: Loss of monoterpenes from Umbellularia californica leaf litter, Biochem. System. Ecol., 23, 581-591, 1995.

Zavarzin, G. A.: Bacteria and Composition of the Atmosphere, Nauka Publisher, Moscow, 1984.

Zimmerman, P. R., Chatfield, R. B., Fishmann, J., Crutzen, P. J., and Hanst, P. L.: Estimates of the production of $\mathrm{CO}$ and $\mathrm{H}_{2}$ from the oxidation of hydrocarbon emissions from vegetation, Geophys. Res. Lett., 5, 679-682, 1978. 